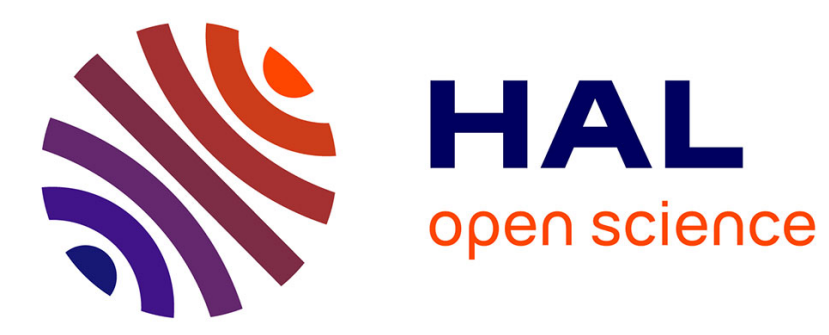

\title{
Dynamic pore-pressure variations induce substrate erosion by pyroclastic flows
}

Olivier Roche, Yarko Niño, Anne Mangeney, Brittany Brand, Nicholas Pollock, Greg Valentine

\section{- To cite this version:}

Olivier Roche, Yarko Niño, Anne Mangeney, Brittany Brand, Nicholas Pollock, et al.. Dynamic porepressure variations induce substrate erosion by pyroclastic flows. Geology, 2013, 41 (10), pp.1107-1110. 10.1130/G34668.1 . hal-00866159

\section{HAL Id: hal-00866159 \\ https://hal.science/hal-00866159}

Submitted on 20 Oct 2017

HAL is a multi-disciplinary open access archive for the deposit and dissemination of scientific research documents, whether they are published or not. The documents may come from teaching and research institutions in France or abroad, or from public or private research centers.
L'archive ouverte pluridisciplinaire HAL, est destinée au dépôt et à la diffusion de documents scientifiques de niveau recherche, publiés ou non, émanant des établissements d'enseignement et de recherche français ou étrangers, des laboratoires publics ou privés. 


\title{
Dynamic pore-pressure variations induce substrate erosion by pyroclastic flows
}

\author{
O. Roche ${ }^{1 *}$, Y. Niño ${ }^{2}$, A. Mangeney ${ }^{3}$, B. Brand ${ }^{4}$, N. Pollock ${ }^{5}$, and G.A. Valentine 6 \\ 'Laboratoire Magmas et Volcans, Université Blaise Pascal, CNRS UMR6524, IRD R163, 5 rue Kessler, F-63038 Clermont-Ferrand, France \\ ${ }^{2}$ Department of Civil Engineering and Advanced Mining Technology Center, University of Chile, Av. Blanco Encalada 2002, Casilla \\ 228-3, Santiago, Chile \\ ${ }_{3}^{3}$ nstitut de Physique du Globe de Paris, Sorbonne Paris Cité, Université Paris Diderot, UMR 7154, 1 rue Jussieu, 75238 Paris \\ cedex 05, France \\ ${ }^{4}$ Department of Geosciences, Boise State University, 1910 University Drive, Boise, Idaho 83725-1535, USA \\ ${ }^{5}$ Department of Earth and Space Sciences, University of Washington, 4000 15th Avenue NE, Seattle, Washington 98195-1310, USA \\ ${ }^{6}$ Department of Geology and Center for Geohazards Studies, University at Buffalo, 411 Cooke Hall, Buffalo, New York 14260-1350, USA
}

\section{ABSTRACT}

Field evidence shows that pyroclastic flows can entrain blocks from underlying substrates formed by earlier geological events, yet, counterintuitively, they are less likely to erode unconsolidated layers of fine particles. Here we report laboratory experiments that reproduce these seemingly contradictory observations and also offer a means to infer pyroclastic flow velocity. Experiments demonstrate that the sliding head of a granular flow generates a dynamic upward pore-pressure gradient at the flow-substrate interface. Associated upward air flux is enough to fluidize a substrate of fines, so that particles are not entrained individually but the substrate instead is subject to small shear instabilities. In contrast, coarse particles forming a non-fluidized substrate are lifted at a critical upward force due to the pore-pressure gradient, according to their individual masses, which provides a basis for a model to calculate the flow velocity. Application to the 18 May 1980 pyroclastic flow deposits at Mount St. Helens (Washington State, USA) gives velocities of $\sim 9-13 \mathrm{~m} \mathrm{~s}^{-1}$ at $\sim 6-7 \mathrm{~km}$ from the vent on gentle slopes $\left(<4^{\circ}-6^{\circ}\right)$, in agreement with field observations at this volcano and at others.

\section{INTRODUCTION}

Pyroclastic flows (PFs) are ground-hugging, dense, gas-particle mixtures generated during volcanic eruptions (Sparks, 1976; Druitt, 1998; Freundt et al., 2000). They may be fluidized at various degrees and thus have negligible to high interstitial pore fluid pressure. High pore pressure greatly reduces internal friction and permits flow for distances up to tens of kilometers even on almost flat topography, rendering PFs highly hazardous. PF dynamics are difficult to directly measure in nature because the flows are unpredictable, dangerous, and often obscured by overriding ash clouds; even simple video recordings are relatively rare (Hoblitt, 1986; Cole et al., 2002; Loughlin et al., 2002). Much of our understanding of PFs is inferred from their deposits, but quantification of dynamics based upon deposit characteristics remains elusive because many processes may be involved. PFs often erode granular substrates over which they propagate (Suzuki-Kamata, 1988; Buesch, 1992; Le Pennec et al., 1994; Sparks et al., 1997; Cole et al., 2002; Pittari et al., 2007; Cas et al., 2011; Pollock and Brand, 2012), similar to other types of geophysical flows though the latter may be less concentrated in particles and have different dynamics (Parker, 1982; Sovilla et al., 2006; Mangeney et al., 2010; Iverson et al., 2011; Louge et al., 2011; McCoy et al., 2012). In this context, the characteristics of the

*E-mail: o.roche@opgc.univ-bpclermont.fr. entrained particles are likely to provide fundamental information on the physical processes involved (Pittari et al., 2007).

\section{FIELD DATA}

Field observations often reveal counterintuitive modes of interaction between PFs and their substrates that depend on the substrate particle size (Fig. 1; details on methods are provided in the GSA Data Repository ${ }^{1}$ ). Meter-sized, dense blocks entrained by PFs are found mixed within the ash matrix of the deposits downstream from the site of erosion as individual clasts or concentrated horizons (Buesch, 1992; Le Pennec et al., 1994; Pittari et al., 2007; Cas et al., 2011; Pollock and Brand, 2012). The blocks' chemical compositions confirm entrainment from the underlying substrate tens to hundreds of meters upstream from their final location in the PF deposits (Buesch, 1992; Pollock and Brand, 2012). For example, PFs produced during the 18 May 1980 eruption of Mount St. Helens (Washington State, USA) entrained blocks from the shattered surface of debris avalanche deposits and transported them tens of meters downstream (Figs. 1A and 1B; Figs. DR1 and DR2 in the Data Repository; Pollock and Brand, 2012).

${ }^{1}$ GSA Data Repository item 2013307, methods, and supplemental figures, tables, and videos, is available online at www.geosociety.org/pubs/ft2013.htm, or on request from editing@geosociety.org or Documents Secretary, GSA, P.O. Box 9140, Boulder, CO 80301, USA.
Evidence for plucking of the blocks is found up to $7.3 \mathrm{~km}$ from the source of the PFs along subhorizontal slopes $\left(<4^{\circ}-5^{\circ}\right)$. A second example includes the voluminous $\left(>640 \mathrm{~km}^{3}\right)$ rhyolitic Miocene Peach Spring Tuff (Arizona, USA) (Buesch, 1992; Valentine et al., 1989), which contains horizons of substrate-derived blocks (granite, basalt) at distances of $\sim 30-90 \mathrm{~km}$ from the vent (Fig. 1C). Rounded basalt blocks derived from local fluvial sediments and older lava surfaces demonstrate unequivocally that the PFs eroded their substrate. Although the exact source location for each boulder is not known, they were derived from within hundreds of meters of their final resting places. In contrast, the Peach Springs Tuff overlies relatively undisturbed deposits of fine, low-density particles (ash) produced by an earlier dry surge or/and fallout (Valentine et al., 1989), suggesting the same flow was surprisingly less able to erode fine-grained substrates (Fig. 1C). A similar example was reported for the Cerro Galan ignimbrite (northwest Argentina; Cas et al., 2011).

\section{EXPERIMENTAL METHODS}

We report the results of 110 laboratory experiments carried out to elucidate the emplacement mechanisms of PFs onto a granular substrate (Tables DR1 and DR2 in the Data Repository). A column of fine (diameter $d=80 \mu \mathrm{m}$ ) particles was released by a lock-exchange system from a reservoir, generating a gravitational flow that propagated along a horizontal substrate in a channel (Fig. 2; for details on our methods, see the Data Repository). After brief acceleration, the flow maintained a nearly constant front velocity $U \sim(g H)^{1 / 2}$, where $H$ was the initial column height and $g$ is the gravitational acceleration, until finally decelerating and rapidly stopping (Roche et al., 2008). The granular flow consisted of a sliding head, which generated a basal underpressure relative to the atmospheric pressure, and of a body with an aggrading basal deposit (Roche et al., 2010; Roche, 2012). For cases where the initial granular column was fluidized, each flow consisted of a dense air-particle mixture with high internal pore fluid pressure and propagated as an inertial fluid gravity 

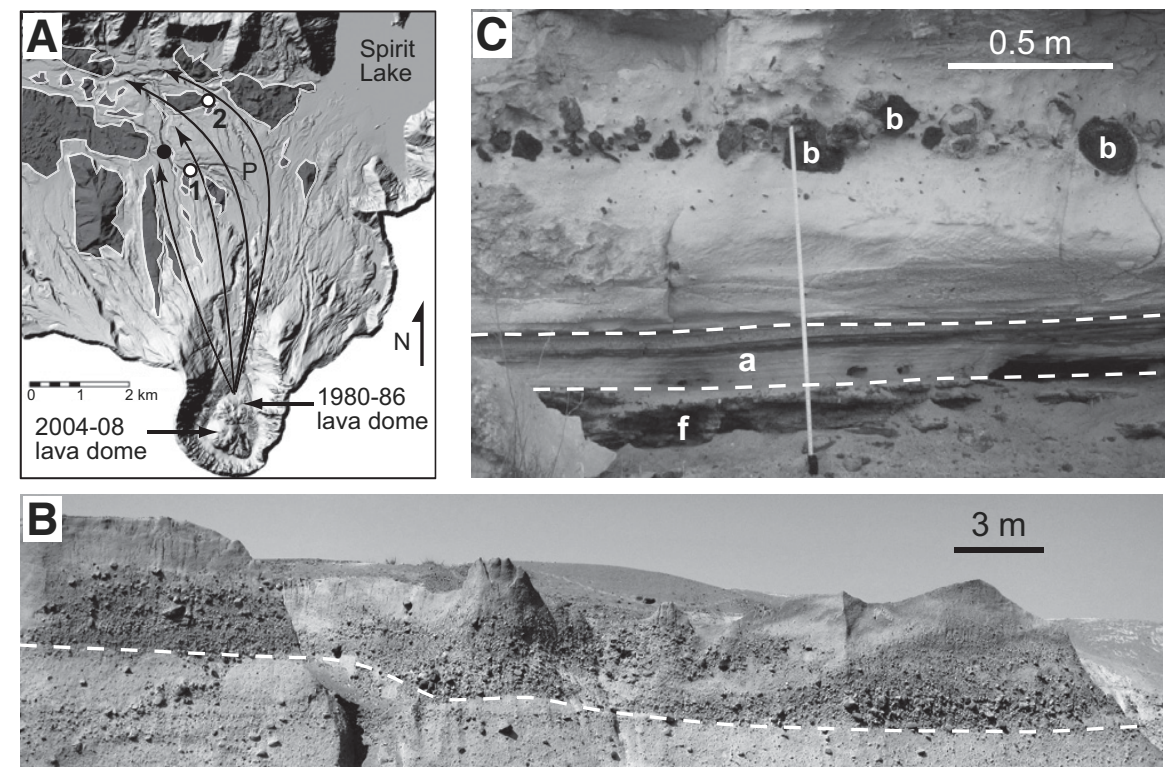

Figure 1. A: Northern sector of Mount St. Helens (MSH; Washington State, USA) with approximate primary paths of pyroclastic flows (arrows). Location of 18 May 1980 debris avalanche deposit and pre-existing obstacles are represented by dark gray areas with white contours. Black dot represents site shown in $B$; white dots with the numbers 1 and 2 represent outcrops in Figures DR1A and DR1B, respectively (see footnote 1). P-pumice plain. B: MSH pyroclastic flow deposit with large lithic blocks entrained from underlying debris avalanche deposit $\left(5.9 \mathrm{~km}\right.$ from vent, local slope $\left.<4^{\circ}-5^{\circ}\right)$. Dashed line is contact between flow units. C: Peach Springs Tuff, Arizona (USA), $\sim 80 \mathrm{~km}$ from vent. b-basalt blocks derived from fluvial sediments located upstream; a-unreworked bed of 1-2 $\mathrm{mm}$ ash; f-fine fluvial sediments.

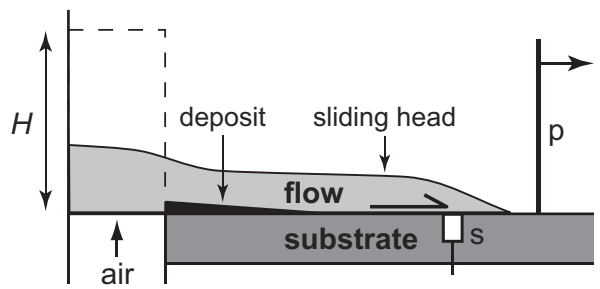

Figure 2. Granular flow resulting from rapid release of column of fine glass particles (diameter $d=80 \mu \mathrm{m}$; particle density $\rho_{\mathrm{p}}$ $=2500 \mathrm{~kg} \mathrm{~m}^{-3}$ ) of height $H$ from reservoir (dashed line). Initially fluidized flows are generated by injecting an air flux at column base. Flow head slides on substrate, which is either rigid or a granular layer leveled by a horizontally translated vertical plate (p). Granular substrate consists of glass $(d=80$ $\mu \mathrm{m}$ or $\left.1500 \mu \mathrm{m}, \rho_{\mathrm{p}}=2500 \mathrm{~kg} \mathrm{~m}^{-3}\right)$ or steel $(d=$ $1590 \mu \mathrm{m}, \rho_{\mathrm{p}}=7850 \mathrm{~kg} \mathrm{~m}^{-3}$ ) beads. Pore fluid pressure is measured with sensors at top of substrate (s).

current for most of its emplacement (Roche et al., 2008, 2010). Scaling considerations were discussed in Roche (2012).

\section{EXPERIMENTAL RESULTS}

Experiments revealed two modes of substrate entrainment by the sliding flow head, depending on the substrate particle size (Fig. 3; Movies DR1-DR3 in the Data Repository). Small wavelike instabilities formed at the interface of the flow and an initially smooth substrate of fine particles $(d=80 \mu \mathrm{m})$. The wavelength and amplitude of these features, which were independent on the flow height, velocity, and state of fluidization, were $\sim 10-15 \mathrm{~mm}$ and $\sim 1 \mathrm{~mm}$, respectively. These structures stretched considerably with time so that any evidence of shearing was barely visible in the final deposit. In contrast, coarse beads $(d=1500$ or $1590 \mu \mathrm{m})$ were entrained individually under the same initial conditions but with a rough substrate possibly subjected to high basal shear stress; entrainment occurred in a zone extending from $\sim 1-3 \mathrm{~cm}$ behind the flow front. The uppermost beads were extracted from their neighbors as fine flow particles surrounded them, and were dragged horizontally along the flow base at a velocity $U_{\mathrm{b}} \approx 0.07 U$, resembling a bedload (e.g., Frey and Church, 2011), while the fine flow particles continued to percolate downward into substrate pore space. At sufficiently high flow velocity, many of the dragged beads were lifted well above their initial position and transported downstream. They then settled and mixed with the fine flow particles at the basal part of the deposit, and most of them stopped motion above the original top of the substrate at a height up to 2-4 times their diameter.

Sensors were used to investigate pore pressure at the top of the substrate. We first measured the maximum relative underpressure caused by the flow head sliding on a rigid substrate, $\Delta P_{\mathrm{r}}$, and we assumed that this had the dimension of a dynamic pressure of the form:

$$
\Delta P_{\mathrm{r}}=\alpha \rho U^{2},
$$

where $\alpha$ is an empirical constant and $\rho$ is the bulk flow density (Fig. 4A). For initially fluidized flows, $\alpha=0.067-0.071$, and for non-fluidized flows, $\alpha=0.031$ (Fig. DR3; note that $\alpha$ might depend on the grain size of the flow particles). Identical experimental conditions with a granular substrate were conducted next. Experiments revealed different types of pressure signals because substrate particles were entrained (individually or as wavelike instabilities), which displaced the flow-substrate interface above the sensors (Fig. DR4 and Movies DR1-DR3). The slowly dragged substrate particles (at velocity $<<U$ ) caused very small underpressures, typically $\sim 0.03 \Delta P_{\mathrm{r}}$, as they passed over the sensors. This demonstrates that interstitial pore pressure below the flow-substrate interface remained almost equal to the atmospheric pressure during entrainment while the underpressure evidenced with a rigid substrate occurred only at the flowsubstrate interface, resulting in an upward pressure gradient.

Our findings suggest that fine particles of a smooth substrate were not entrained individually because the flow particles could not penetrate into substrate pore space. However, an upward air flux resulting from the pore-pressure gradient likely fluidized the substrate (see the Data Repository). Hence, the relative flow-substrate velocity generated the observed sheared wavelike structures, which were similar to KelvinHelmholtz instabilities (Rowley et al., 2011; Farin et al., 2013). In contrast, a substrate of coarse particles could not be fluidized for the size and weight of particles in these experiments. Instead, the coarse beads were surrounded by the fine flow particles and were first dragged individually along the flow base. The height of subsequent uplift was a function of pressure conditions at the flow-substrate interface (i.e., top of dragged beads), which was in turn controlled by the flow velocity (Fig. 4B). Underpressure at the top of the beads was estimated from Equation 1 taking into account the relative flow-substrate velocity such that

$$
\Delta P_{\text {top }}=\alpha \rho\left(U-U_{\mathrm{b}}\right)^{2} .
$$

Considering $U_{\mathrm{b}} \approx 0.07 U$ (see above), the pressure just above the beads was $P_{1} \approx P_{\mathrm{a}}-\Delta P_{\text {top }}$, or $P_{1}$ $\approx P_{\mathrm{a}}-0.86 \Delta P_{\mathrm{r}}$, where $P_{\mathrm{a}}$ is the atmospheric pressure. Considering the actual pore pressure in the substrate $P_{2} \approx P_{\mathrm{a}}-0.03 \Delta P_{\mathrm{r}}$ (see above), dragged beads were subjected to a pressure difference:

$$
\Delta P=P_{2}-P_{1}=\lambda \Delta P_{r}=\lambda \alpha \rho U^{2},
$$

with $\lambda=0.83$. Bead uplift could occur at a critical pressure difference $\Delta P_{\mathrm{c}}=m g / S$, where $m$ is the particle mass and $S$ is the effective area to which the upward force due to the pressure 


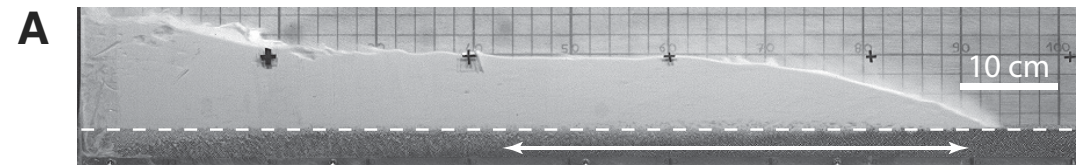

B
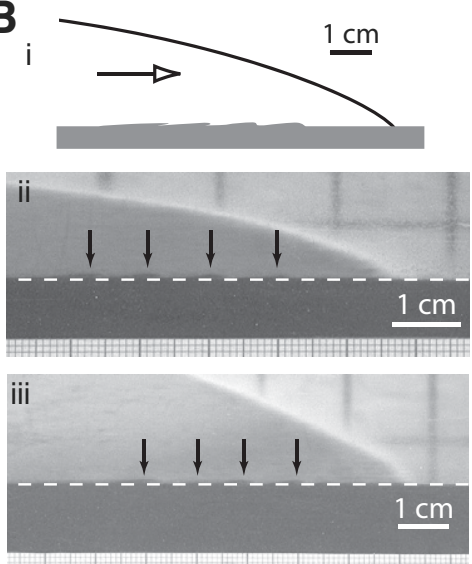

C
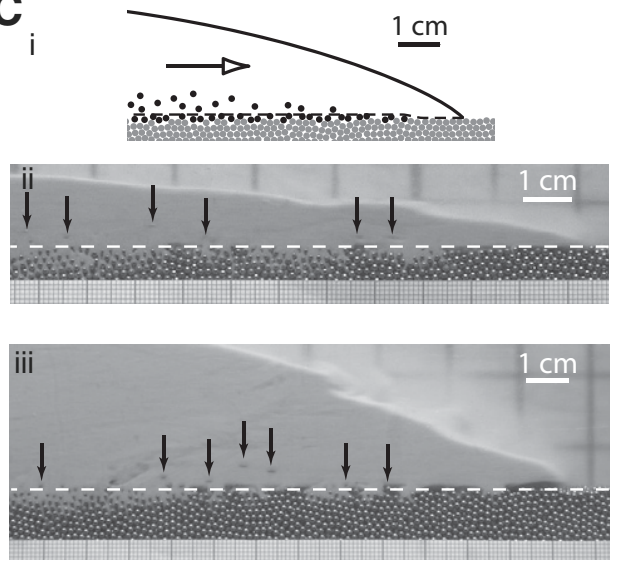

Figure 3. Initially fluidized flows of fine glass beads (diameter $d=80 \mu \mathrm{m}$ ), with original top of substrate indicated by a dashed line on photos. A: General view of flow on substrate of coarse steel beads $(d=1590 \mu \mathrm{m})$, with substrate entrainment zone at base of sliding head indicated by double arrow (see Movie DR1 [see footnote 1]). B: Flow on substrate of fine black glass beads $(d=80 \mu \mathrm{m})$. i-sketch showing small shearing wavelike instabilities at top of substrate (indicated by arrows in photos below); ii- flow front velocity $U=1.46 \mathrm{~m} \mathrm{~s}^{-1}$; iii-U $=2.60 \mathrm{~m} \mathrm{~s}^{-1}$ (see Movie DR2). C: Flow on substrate of coarse steel beads $(d=1590 \mu \mathrm{m})$. $\mathrm{i}-$ sketch showing static beads (gray) and those dragged and then uplifted (black; respectively below and above the dashed line, the latter indicated by arrows in photos below); $\mathrm{ii}-U=$ $1.63 \mathrm{~m} \mathrm{~s}^{-1}$; iii-U $=2.55 \mathrm{~m} \mathrm{~s}^{-1}$ (see Movie DR3).
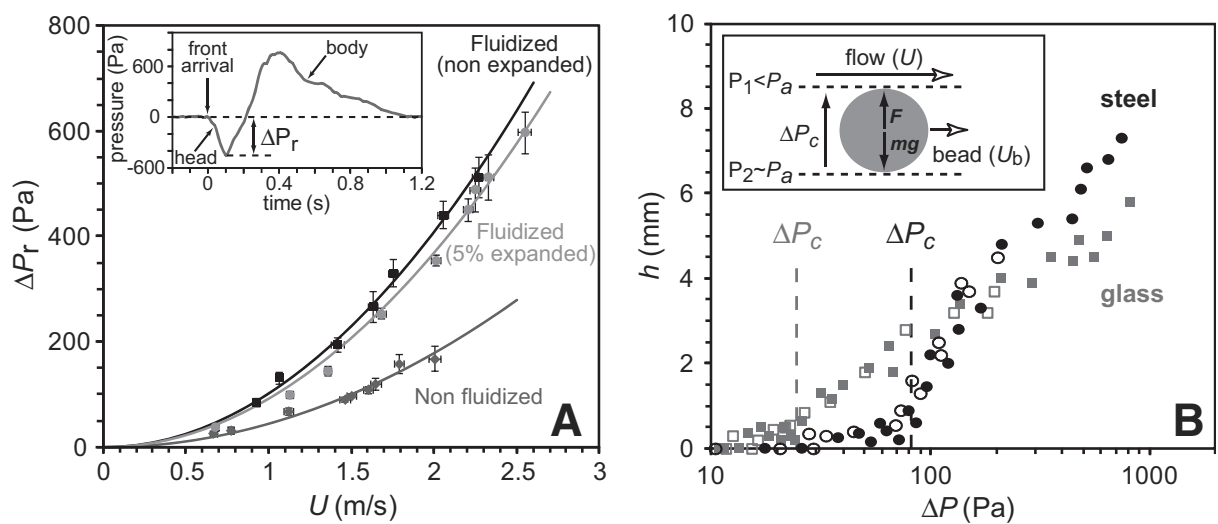

Figure 4. A: Maximum relative underpressure on rigid substrate, $\Delta P_{r}$ (in pascals, see inset), as function of flow front velocity, $U$, for initially fluidized and slightly expanded $(\sim 4 \%-5 \%$, $\left.\alpha=0.067, \rho \approx 1380 \mathrm{~kg} \mathrm{~m}^{-3}\right)$ or non-expanded $\left(\alpha=0.071, \rho \approx 1450 \mathrm{~kg} \mathrm{~m}^{-3}\right)$ flows, and for nonfluidized flows $\left(\alpha=0.031, \rho \approx 1450 \mathrm{~kg} \mathrm{~m}^{-3}\right)$. B: Maximum height of uplift of coarse substrate particles $(h)$ as function of pressure difference $(\Delta P$, in pascals) between flow base and substrate. Squares and circles are glass (diameter $d=1500 \mu \mathrm{m})$ and steel $(d=1590 \mu \mathrm{m})$ beads, respectively. Plain and open symbols are fluidized and non-fluidized flows, respectively. Inset: Flow of velocity $U$ dragging substrate bead at velocity $U_{b} \approx 0.07 U$ above its static counterparts (see text). $\boldsymbol{P}_{\mathrm{a}}$-atmospheric pressure, $\Delta \boldsymbol{P}_{\mathrm{c}}$-critical pressure difference at onset of uplift (at $F=m g$, where $F$ is force, $\boldsymbol{m}$ is particle mass, and $g$ is gravitational acceleration).

gradient was applied. For spherical beads of diameter $d, S=\pi d^{2} / 4$, so that:

$$
\Delta P_{\mathrm{c}, \mathrm{sphere}}=\frac{2}{3} \rho_{\mathrm{p}} g d,
$$

where $\rho_{\mathrm{p}}$ is the particle density. Experiments showed that below $\Delta P_{\text {c,sphere }}$, horizontally dragged beads rose gently $(<\sim 0.5 \mathrm{~mm})$ as they at a given pressure gradient generated by initially fluidized or non-fluidized flows, whose velocity differed by a factor of about two. Hence, maximum uplift may have resulted from higher initial momentum as $\Delta P$ increased. Complementary experiments demonstrated that first evidence of uplift occurred shortly after $\Delta P_{\mathrm{c}, \text { sphere }}$ was attained and that severe reduction of the effective substrate roughness (caused by fine particles filling the network of coarse beads up to the bed top) inhibited individual entrainment of the coarse particles and instead promoted small shear structures as in monodisperse smooth substrates of fines (Fig. DR5 and Movies DR4-DR5).

\section{APPLICATION TO PYROCLASTIC FLOWS}

We now apply our model to the Mount St. Helens 18 May 1980 PF deposits in order to infer flow velocities from the properties of entrained blocks. We measured the size of the five largest blocks at sites 1 and 2 in Figure 1, considering them as parallelepipeds with sides of length $x>y>z$ (Fig. DR1). Assuming the blocks were uplifted with their largest face $(x y)$ horizontal and their short axis (z) vertical (i.e., condition of minimum energy), then according to our analysis the critical pressure difference for a parallelepiped is:

$$
\Delta P_{\text {c,parall }}=\rho_{\mathrm{p}} g z .
$$

Combining Equations 3 and 5, we obtain the critical flow velocity for uplift:

$$
U=\sqrt{\frac{\rho_{\mathrm{p}} g z}{\lambda \alpha \rho}} .
$$

The largest blocks are andesites $\left(\rho_{\mathrm{p}} \sim 2600 \mathrm{~kg}\right.$ $\mathrm{m}^{-3}$ ) with mean $z=0.35 \mathrm{~m}$ and $0.25 \mathrm{~m}$, at site 1 ( $\sim 5.6 \mathrm{~km}$ from vent) and site $2(\sim 7.2 \mathrm{~km}$ from vent), respectively (Table DR3). For calculation we assumed that (1) $\lambda=0.83$ and $\alpha=0.069$ (mean value), as in experiments involving fluidized flows and substrates of coarse particles, and (2) pyroclastic flows had a maximum bulk density $\rho \approx 1400 \mathrm{~kg} \mathrm{~m}^{-3}$, equal to that of the deposit matrix, or a minimum value $\rho \approx 875 \mathrm{~kg} \mathrm{~m}^{-3}$ corresponding to a maximum expansion of $\sim 60 \%$ as shown by laboratory studies (Druitt et al., 2007; Girolami et al., 2010). Equation 6 gives $U$ $=10.5-13.3 \mathrm{~m} \mathrm{~s}^{-1}$ at site 1 and $U=8.9-11.2 \mathrm{~m}$ $\mathrm{s}^{-1}$ at site 2 (note that Equation 4 for spherical blocks gives velocities of $\sim 0.82 U$ ). These values are meant to be actual flow velocities, rather than minimum values, because potentially larger blocks than those entrained were not moved and still reside on the substrate upstream. They are close to velocities reported from video recordings for PFs (1) of 7 August 1980 at Mount St. Helens at the same distance from the vent ( $U \approx 7-10 \mathrm{~m} \mathrm{~s}^{-1}$ at $\sim 5-5.5 \mathrm{~km}$; Hoblitt, 1986, his figure 13) and (2) at Soufrière Hills, Montserrat $\left(U \approx 10-20 \mathrm{~m} \mathrm{~s}^{-1}\right.$, distance and topography 
similar to that at Mount St. Helens; Cole et al., 2002; Loughlin et al., 2002). Our model applied to the Peach Springs Tuff containing basaltic blocks $\left(\rho_{\mathrm{p}} \approx 2900 \mathrm{~kg} \mathrm{~m}^{-3}\right.$ ) of size up to $z \approx 0.5 \mathrm{~m}$ (Buesch, 1992) gives minimum velocities of $\sim 13.2-16.7 \mathrm{~m} \mathrm{~s}^{-1}$. From the data of Pittari et al. (2007) and Cas et al. (2011), Equation 6 gives minimum velocities that are 2.5-3.1 times larger than those previously calculated $\left(\sim 2.5-4.5 \mathrm{~m} \mathrm{~s}^{-1}\right.$ at $\rho \approx 1400 \mathrm{~kg} \mathrm{~m}^{-3}$ ) for the Abrigo (Canary Islands) and Cerro Galan ignimbrites based upon the hypothesis of block displacement at flow base through aerodynamic drag. Furthermore, the uplift mechanism we report can explain why entrained blocks are often found in deposits well above the top of the substrate.

\section{CONCLUSIONS}

Our experiments demonstrate that basal underpressure at the head of granular flows, as also reported for snow avalanches, for instance (e.g., McElwaine and Turnbull, 2005), is a dynamic phenomenon as it varies with the square of the flow velocity. The entrainment mechanism of a relatively rough substrate of coarse particles by a granular flow revealed by our study shares similarities with that of single-phase fluid flows for which erosion obeys the Shield's criterion and produces particle saltation (Niño et al., 2003), but the shear stress and vertical forces over the substrate particles are of different nature. This mechanism not only explains the apparent dichotomy that geophysical granular flows such as PFs are able to entrain decimetersized blocks while often leaving finely grained substrates relatively undisturbed (Fig. 1C), but it also provides a method to invert data from $\mathrm{PF}$ deposits by constraining flow velocities based on the size and density of entrained blocks (e.g., Pittari et al., 2007). The method we propose may be applicable to other types of geophysical flows, to explain and quantify conditions that promote substrate entrainment as shown by our experiments.

\section{ACKNOWLEDGMENTS}

This work was supported by the Institut de Recherche pour le Développement (IRD, France), the ECOSConicyt C11U01 (France-Chile), and the French ANR PLANETEROS and LANDQUAKES projects. This is Laboratory of Excellence ClerVolc contribution number 64 and IPGP contribution number 3408 .

\section{REFERENCES CITED}

Buesch, D.C., 1992, Incorporation and redistribution of locally derived lithic fragments within a pyroclastic flow: Geological Society of America Bulletin, v. 104, p. 1193-1207, doi:10.1130/0016 -7606(1992)104<1193:IAROLD>2.3.CO;2.

Cas, R.A.F., Wright, H.M.N., Folkes, C.B., Lesti, C., Porreca, M., Giordano, G., and Viramonte, J.G., 2011, The flow dynamics of an extremely large volume pyroclastic flow, the 2.08-Ma Cerro Galán Ignimbrite, NW Argentina, and comparison with other flow types: Bulletin of Volcanology, v. 73, p. 1583-1609, doi:10.1007/s00445-011 $-0564-\mathrm{y}$.
Cole, P.D., Calder, E.S., Sparks, R.S.J., Clarke, A.B., Druitt, T.H., Young, S.R., Herd, R.A., Harford, C.L., and Norton, G.E., 2002, Deposits from dome-collapse and fountain-collapse pyroclastic flows at Soufrière Hills Volcano, Montserrat, in Druitt, T.H., and Kokelaar, B.P., eds., The Eruption of Soufrière Hills Volcano, Montserrat, from 1995 to 1999: Geological Society of London Memoir 21, p. 231-262.

Druitt, T.H., 1998, Pyroclastic density currents, in Gilbert, J.S., and Sparks, R.S.J., eds., The Physics of Explosive Volcanic Eruptions: Geological Society of London Special Publication 145, p. 145-182.

Druitt, T.H., Avard, G., Bruni, G., Lettieri, P., and Maez, F., 2007, Gas retention in fine-grained pyroclastic flow materials at high temperatures: Bulletin of Volcanology, v. 69, p. 881-901, doi:10.1007/s00445-007-0116-7.

Farin, M., Mangeney, A., and Roche, O., 2013, Erosion processes in granular flows: Insights from laboratory experiments: European Geophysical Union Meeting, 2013, Abstract EGU2013-610.

Freundt, A., Carey, S., and Wilson, C.J.N., 2000, Ignimbrites and block-and-ash flow deposits, in Sigurdsson, H., et al., eds., Encyclopedia of Volcanoes: New York, London, Academic Press, p. 581-600.

Frey, P., and Church, M., 2011, Bedload: A granular phenomenon: Earth Surface Processes and Landforms, v. 36, p. 58-69, doi:10.1002/esp .2103 .

Girolami, L., Roche, O., Druitt, T.H., and Corpetti, T., 2010, Velocity fields and depositional processes in laboratory ash flows: Bulletin of Volcanology, v. 72, p. 747-759, doi:10.1007 /s00445-010-0356-9.

Hoblitt, R.P., 1986, Observations of the eruptions of July 22 and August 7, 1980, at Mount St. Helens, Washington: U.S Geological Survey Professional Paper 1335, 42 p.

Iverson, R.M., Reid, M.E., Logan, M., LaHusen, R.G., Godt, J.W., and Griswold, J.G., 2011, Positive feedback and momentum growth during debris-flow entrainment of wet bed sediment: Nature Geoscience, v. 4, p. 116-121, doi:10.1038/ngeo1040.

Le Pennec, J.-L., Bourdier, J.-L., Froger, J.-L., Temel, A., Camus, G., and Gourgaud, A., 1994, Neogene ignimbrites of the Nevsehir plateau (central Turkey): Stratigraphy, distribution and source constraints: Journal of Volcanology and Geothermal Research, v. 63, p. 59-87, doi:10.1016/0377-0273(94)90018-3.

Louge, M., Carroll, C.S., and Turnbull, B., 2011, Role of pore pressure gradients in sustaining frontal particle entrainment in eruption currents-The case of powder snow avalanches: Journal of Geophysical Research, v. 116, F04030, doi:10.1029/2011JF002065.

Loughlin, S.C., Calder, E.S., Clarke, A., Cole, P.D., Luckett, R., Mangan, M.T., Pyle, D.M., Sparks, R.S.J., Voight, B., and Watts, R.B., 2002, Pyroclastic flows and surges generated by the 25 June 1997 dome collapse, Sonfière Hills Volcano, Montserrat, in Druitt, T.H., and Kokelaar, B.P., eds., The Eruption of Soufrière Hills Volcano, Montserrat, from 1995 to 1999: Geological Society of London Memoir 21, p. 191-209.

Mangeney, A., Roche, O., Hungr, O., Mangold, N., Faccanoni, G., and Lucas, A., 2010, Erosion and mobility in granular collapse over sloping beds: Journal of Geophysical Research, v. 115, F03040, doi:10.1029/2009JF001462.

McCoy, S.W., Kean, J.W., Coe, J.A., Tucker, G.E., and Staley, D.M., 2012, Sediment entrainment by debris flows: In situ measurements from the headwaters of a steep catchment: Journal of Geophysical Research, v. 117, F03016, doi:10.1029 /2011JF002278.

McElwaine, J.N., and Turnbull, B., 2005, Air pressure data from the Vallée de la Sionne avalanches of 2004: Journal of Geophysical Research, v. 110, F03010, doi:10.1029/2004JF000237.

Niño, Y., Lopez, F., and Garcia, M., 2003, Threshold for particle entrainment into suspension: Sedimentology, v. 50, p. 247-263, doi:10.1046/j.1365 $-3091.2003 .00551 . x$.

Parker, G., 1982, Conditions for the ignition of catastrophically erosive turbidity currents: Marine Geology, v. 46, p. 307-327, doi:10.1016/0025 -3227(82)90086-X.

Pittari, A., Cas, R.A.F., Monaghan, J.J., and Martí, J., 2007, Instantaneous dynamic pressure effects on the behaviour of lithic boulders in pyroclastic flows: The Abrigo Ignimbrite, Tenerife, Canary Islands: Bulletin of Volcanology, v. 69, p. 265279, doi:10.1007/s00445-006-0072-7.

Pollock, N.M., and Brand, B.D., 2012, Investigation into the erosive capacity of pyroclastic density currents at Mount Saint Helens, Washington (USA): American Geophysical Union fall meeting, San Francisco, California, Abstract V54C-01.

Roche, O., 2012, Depositional processes and gas pore pressure in pyroclastic flows: An experimental perspective: Bulletin of Volcanology, v. 74, p. 1807-1820, doi:10.1007/s00445-012-0639-4.

Roche, O., Montserrat, S., Niño, Y., and Tamburrino, A., 2008, Experimental observations of waterlike behavior of initially fluidized, unsteady dense granular flows and their relevance for the propagation of pyroclastic flows: Journal of Geophysical Research, v. 113, B12203, doi:10.1029 /2008JB005664.

Roche, O., Montserrat, S., Niño, Y., and Tamburrino, A., 2010, Pore fluid pressure and internal kinematics of gravitational laboratory air-particle flows: Insights into the emplacement dynamics of pyroclastic flows: Journal of Geophysical Research, v. 115, B09206, doi:10.1029 /2009JB007133.

Rowley, P.J., Kokelaar, P., Menzies, M., and Waltham, D., 2011, Shear-derived mixing in dense granular flows: Journal of Sedimentary Research, v. 81, p. 874-884, doi:10.2110/jsr.2011.72.

Sovilla, B., Burlando, P., and Bartelt, P., 2006, Field experiments and numerical modeling of mass entrainment in snow avalanches: Journal of Geophysical Research, v. 111, F03007, doi:10.1029 /2005JF000391.

Sparks, R.S.J., 1976, Grain size variations in ignimbrites and implications for the transport of pyroclastic flows: Sedimentology, v. 23, p. 147-188, doi:10.1111/j.1365-3091.1976.tb00045.x.

Sparks, R.S.J., Gardeweg, M.C., Calder, E.S., and Matthews, S.J., 1997, Erosion by pyroclastic flows on Lascar Volcano, Chile: Bulletin of Volcanology, v. 58, p. 557-565, doi:10.1007/s004450050162.

Suzuki-Kamata, K., 1988, The ground layer of Ata pyroclastic flow deposit, southwestern Japan-Evidence for the capture of lithic fragments: Bulletin of Volcanology, v. 50, p. 119-129, doi:10.1007 /BF01275173.

Valentine, G.A., Buesch, D.C., and Fisher, R.V.,1989, Basal layered deposits of the Peach Springs Tuff, northwestern Arizona, USA: Bulletin of Volcanology, v. 51, p. 395-414, doi:10.1007 /BF01078808. 